\title{
Ethyl Lactate Production from the Catalytic Depolymerisation of Post-consumer Poly(lactic acid)
}

\author{
Luis A. Román-Ramírez ${ }^{1} \cdot$ Mark Powders $^{1} \cdot$ Paul McKeown $^{2} \cdot$ Matthew D. Jones $^{2} \cdot$ Joseph Wood $^{1}$ (D)
}

Published online: 17 July 2020

(c) The Author(s) 2020

\begin{abstract}
Bioplastics such as poly(lactic acid) (PLA), which are derived from renewable sources, promoted as biodegradable and implemented for numerous functions, offer a promising alternative to the enduring synthetic plastics abundant in society. However, the degradation of PLA is slow under natural environmental conditions. A chemical recycling route is thus required to couple mitigation of plastic persistence repercussions with circular economy adherence. In the present work, the production of ethyl lactate by the catalysed transesterification of post-consumer PLA was investigated. The catalyst employed was a propylendiamine $\mathrm{Zn}(\mathrm{II})$ complex. The PLA samples investigated consisted of a phone case, an infant's toy, a film, a cup and 3D printing material. Degradation reactions were studied at $50{ }^{\circ} \mathrm{C}$ and $90{ }^{\circ} \mathrm{C}$ and the concentrations measured at two different time intervals, $1 \mathrm{~h}$ and $3 \mathrm{~h}$. The results revealed that greater activity of the catalyst was observed at $50^{\circ} \mathrm{C}$ for two PLA samples (cup, 3D print). PLA film achieved the greatest lactate yield (71\%) of all samples after $3 \mathrm{~h}$ at $50{ }^{\circ} \mathrm{C}$. It is concluded that the propylenediamine $\mathrm{Zn}$ (II) catalyst can be used to produce green solvent ethyl lactate at mild temperatures from post-consumer PLA, even in the presence of unknown additives.
\end{abstract}

Keywords Ethyl lactate $\cdot$ Poly (lactic acid) $\cdot$ Depolymerisation $\cdot$ Renewable chemicals $\cdot$ Catalysis

\section{Introduction}

Plastics in society have become ubiquitous. Their intrinsic properties such as electrical insulation, low density and chemical resistance have enabled utility in a wide variety of applications, including packaging, electrical and transportation [1]. It is estimated that $8300 \mathrm{Mt}$ of synthetic plastics have been produced globally to date; of these, only $9 \%$ by mass of waste plastics are recycled, $79 \%$ are discarded in landfills or the natural environment and $12 \%$ incinerated [2]. Furthermore, plastic degradation takes hundreds of years under natural conditions [3]. On an extensive scale, these waste plastics which accumulate on land and in the oceans inflict damage upon the environment [2]. The ingestion

Matthew D. Jones

mj205@bath.ac.uk

$\triangle$ Joseph Wood

j.wood@bham.ac.uk

1 School of Chemical Engineering, University of Birmingham, Edgbaston, Birmingham B15 2TT, UK

2 Department of Chemistry, University of Bath, Claverton Down, Bath BA2 7AY, UK of waste plastics by marine life, for instance, culminates in intestinal tract blockage, lower food uptake and death; ingesting plastic debris (microplastics) comprising of chemical pollutants contaminates food chains and raises toxicity with each successive trophic level [4]. Exposure to persistent organic pollutants such as polychlorinated biphenyls (PCBs) found in microplastics, have adverse health effects, including reproductive abnormalities, carcinogenesis and acute lethality [5]. To a lesser extent, commercial fishing equipment debris instigates plastic entanglement that suffocates and lacerates turtles, mammals and birds [4].

In contrast to petroleum-derived plastics, bioplastics are, in principle, biodegradable under environmental parameters, generated from renewable biomass feedstock and incorporate non-toxic additives to enhance performance. Various bioplastic grades are currently utilised for numerous applications ranging from medical to agriculture [6]. The adoption of bioplastics into society effectively lessens reliance upon non-renewable feedstocks, reduces the need for harmful and unsustainable waste management schemes and decreases the unacceptable damage that synthetic plastics and associated pollutants inflict upon the environment. 
A bioplastic that has risen in demand in recent years is poly(lactic acid) (PLA), mainly driven by changing attitudes towards the environment coupled with the progression in polymer manufacturing. PLA for instance is used in applications like packaging, cups and food serviceware, films, rigid consumer goods, textiles applications, nonwoven products, among many others [6-8]. The global bioplastic packaging consumption alone is projected to rise over $16 \%$ yearly [9], highlighting the market potential of PLA.

Although PLA is, in principle, biodegradable, in reality under mild conditions the degradation times are slow and result in prolonged persistence [6]. Studies on PLA degradation in terrestrial crude soil indicate little distinction over many weeks; moreover, the central microbial activity causes the $\mathrm{pH}$ to rise markedly, endangering the culture and local plant life $[10,11]$. In water, at ambient temperatures around $23{ }^{\circ} \mathrm{C}$, similar slow progress is observed, whereas at scarcer thermophilic temperatures, degradation is faster [12]. Sensible PLA waste management is therefore required in order to evade the adverse environmental consequences of persistent PLA [4, 13, 14]. Since potentially harmful management schemes entailing landfilling and incineration offer an unsustainable non-cyclic approach, mechanical recycling is in this case a preferred option [15]. Mechanically recycled waste material, however, become downgraded by means of several recycling loops. Downgraded recycled products suffer from poor performances and are thus of less economic value [16]. Chemical recycling is a promising alternative recycling method over mechanical recycling. Dissimilar to mechanical, chemical recycling of PLA can acquire a product of the same quality as the virgin material [17], or produce valuable chemicals in an economically and environmentally sustainable manner [18].

Conceivable routes for the chemical recycling of PLA include hydrolytic degradation [19], thermal degradation $[20,21]$, enzymatic processes $[22,23]$ and the transesterification reaction [24]. Nevertheless, to achieve significant degradation, the former two must operate under high temperatures exceeding $160^{\circ} \mathrm{C}$, accruing large energy costs. Enzymatic processes present a sustainable and efficient option, yet are limited in the energy sector by a lack of development for stable immobilized biocatalysts, currently hampering its industrial-scale application [25]. Thermal catalytic depolymerisation of PLA, can proceed independently prior to esterification. Noda and Okuyama [26] reported the use of numerous metallic catalysts over a temperature range of $190-245^{\circ} \mathrm{C}$. A conventionally employed stannous catalyst $\left\{\mathrm{Sn}(\mathrm{Oct})_{2}\right\}$ instigated a high lactide (the dimer of lactic acid) yield of $89 \%$ in $1 \mathrm{~h}$, outperforming alternatives which exhibited low yields and low activity despite high catalyst loading. However, in addition to high operating temperatures, $\mathrm{Sn}(\mathrm{oct})_{2}$ is an expensive and toxic catalyst. The hydrolytic depolymerisation under milder temperatures $\left(40-120^{\circ} \mathrm{C}\right)$ and acidic conditions has also been reported [27].

Depolymerisation of PLA, initiated by the addition of a protic low molecular weight alcohol, such as ethanol, proceeds by the transesterification of PLA (Fig. 1) [28]. The product ethyl lactate (EtLa), described as a biodegradable 'green' solvent with low toxicity, can be employed in place of established petroleum-derived solvents such as acetone and toluene [29]. EtLa has long found a wide sphere of applications from use in pharmaceutical, food, coating and cosmetic formulations [28]. Additionally, as a fundamental
Fig. 1 Poly(lactic acid) polymerisation and depolymerisation with a Zn(II) catalyst complex and their fit in a circular economy process

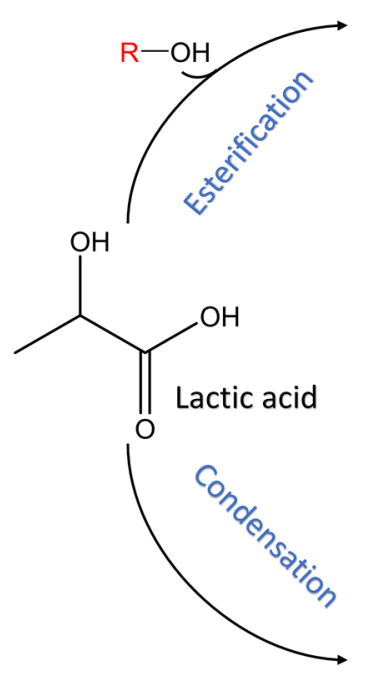

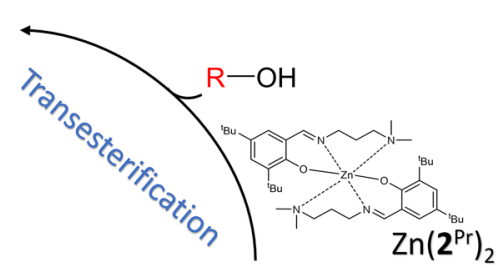

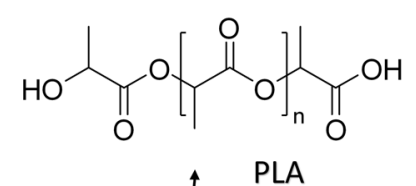

Lactide<smiles>CC1OC(=O)C(C)OC1=O</smiles>

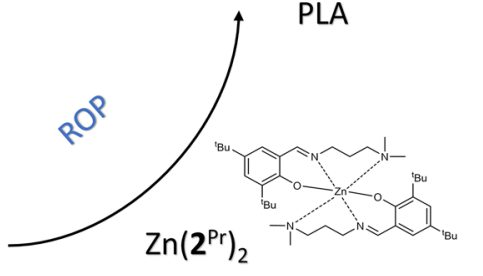


reagent, ethanol is readily produced globally from a sustainable biomass feedstock [28]. Research has also demonstrated the possibility of lactide recovery from alkyl lactates, therefore enabling PLA reformation [30-34]. In particular, ethyl lactate seems to attain a greater lactide yield than other low molecular weight alkyl lactates [33]. Furthermore, the successive esterification of lactic acid (or lactide) into lactates directed by an acid catalyst with a protic alcohol has also been shown [35-37], consequently showing the possibility of a circular economy (Fig. 1).

Various catalysed processes have been devised for the transesterification of PLA into lactates [24, 38-43]. Processes include patents for the use of acid catalysts for direct transesterification [40, 44]. DuPont, for instance, has patented a process entailing the production of alkyl lactates alongside a liquid acid catalyst [40]; PLA conversion to EtLa stands at $78 \%$ when subjected to $150{ }^{\circ} \mathrm{C}$ for $2 \mathrm{~h}$ in the presence of $\mathrm{H}_{2} \mathrm{SO}_{4}$. Since water in the vicinity competes and limits conversion, excess alcohol, catalysts, inert atmosphere and efficient separation are essential for successful alkyl lactate synthesis [41]; also, the quenching and neutralisation steps at the conclusion of a reaction can consume liquid acid catalysts producing undesirable waste salts. Solid acid catalysts, such as silica supported $\mathrm{H}_{2} \mathrm{SO}_{4}$, present a promising green opportunity that ensures facile separation, reuse of catalyst and reduction in toxic waste disposal costs [45]. Refraining from the employment of acid catalysts, Song et al. [46] reported the potential for novel ionic initiators to control the methanolysis of PLA; 1-butyl3-methylimidazolium acetate ([Bmim][AcO $]$ ) was found to achieve high methyl lactate (MeLa) yields up to $92.5 \%$, whilst operating at a relatively low temperature $\left(115^{\circ} \mathrm{C}\right)$, in $3 \mathrm{~h}$. Further investigations identified the ease of catalyst separation by distillation and the ability for re-use up to 6 times before substantial conversion and yield reduction ensued. Organic catalysts such as triazabicyclodecene (TBD) offer a distinguished route to produce alkyl lactates at high yields in a short time under mild conditions [39]; the use of halogenated solvents was unfortunately necessary, reducing the green credential of the process.

Employing a range of catalysts and microwave heating, Enthaler and co-workers [47-49] have successfully degraded several PLA waste samples into MeLa at temperature higher than $120^{\circ} \mathrm{C}$. The lactate yield varied depending on reaction time, catalyst concentration, sample and temperature.

Recently, Jones et al. [24, 42, 50] utilised a Zn(II) catalyst complex $\left\{\mathrm{Zn}\left(1^{\mathrm{Et}}\right)_{2}\right\}$ in the presence of protic methanol to degrade several neat and post-consumer PLA grades into MeLa. Observations on the depolymerization of PLA into MeLa by $\mathrm{Zn}\left(\mathbf{1}^{\mathrm{Et}}\right)_{2}$ indicated no mass-transfer limitations, a positive correlation between temperature and reaction rate, lower activation energy with increased catalyst loading and an agreement with a 1st order two-step kinetic model [24].
To further establish viability on an industrial-scale, catalyst stability was determined. The post-consumer PLA was successfully degraded to MeLa even with unknown additives in the samples [50]. Building upon the promising work of Jones and co-workers, in the current research, the catalytic depolymerisation of post-consumer PLA samples into EtLa is examined at $50^{\circ} \mathrm{C}$ and $90{ }^{\circ} \mathrm{C}$. Furthermore, an alternative catalyst $\left\{\mathrm{Zn}\left(2^{\mathrm{Pr}}\right)_{2}\right\}$ is employed which has been observed as displaying greater activity at lower temperatures than $\mathrm{Zn}\left(\mathbf{1}^{\mathrm{Et}}\right)_{2}[42,43] . \mathrm{Zn}\left(\mathbf{2}^{\mathrm{Pr}}\right)_{2}$ has also been used for the production of PLA from the ring-opening polymerisation (ROP) of lactide (Fig. 1) [43], demonstrating the utility of the catalyst for both, PLA production and PLA depolymerisation. The research by McKeown et al. [43] on $\mathrm{Zn}\left(\mathbf{2}^{\mathrm{Pr}}\right)_{2}$ (Fig. 2) led to the proposal that not only at $50{ }^{\circ} \mathrm{C}$ does the transesterification process become more energy cost-effective but even faster. $90^{\circ} \mathrm{C}$ was decided based upon previous literature where at this temperature relatively high yields were achieved in $1 \mathrm{~h}$ [24].

\section{Methods and Materials}

The reactions were performed in a $300 \mathrm{~mL}$ T316 stainless steel stirred jacketed pressure reactor (PARR 4566 series). Control of stirring speed and the monitoring of pressure was conducted using a reactor controller (PARR 4848 series). Internal reactor temperature was controlled by a heating circulator (Julabo HE) which pumped heated oil through the jacket. The internal temperature of the reactor was measured by a Pt100 sensor. The amount of the PLA and catalyst were measured using a OHAUS Explorer Pro balance.

The post-consumer PLA samples studied consisted of a phone case, an infants' toy, a film, a cup and 3D printed material (Fig. 3). The choice of samples was made to demonstrate the applicability of the recycling process on a variety of products with different molecular weights. The

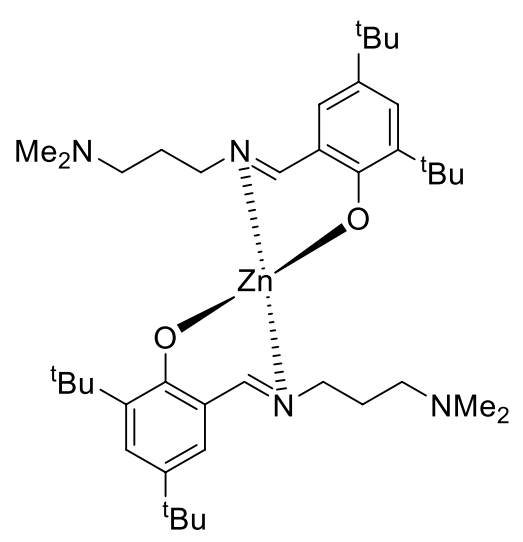

Fig. 2 Structure of the $\mathrm{Zn}\left(2^{\mathrm{Pr}}\right)_{2}$ catalyst employed in the experiments 
Fig. 3 Post-consumer PLA samples used (excluding film): toys (upper left), 3D printed material (bottom left), phone case (centre) and cup (right)

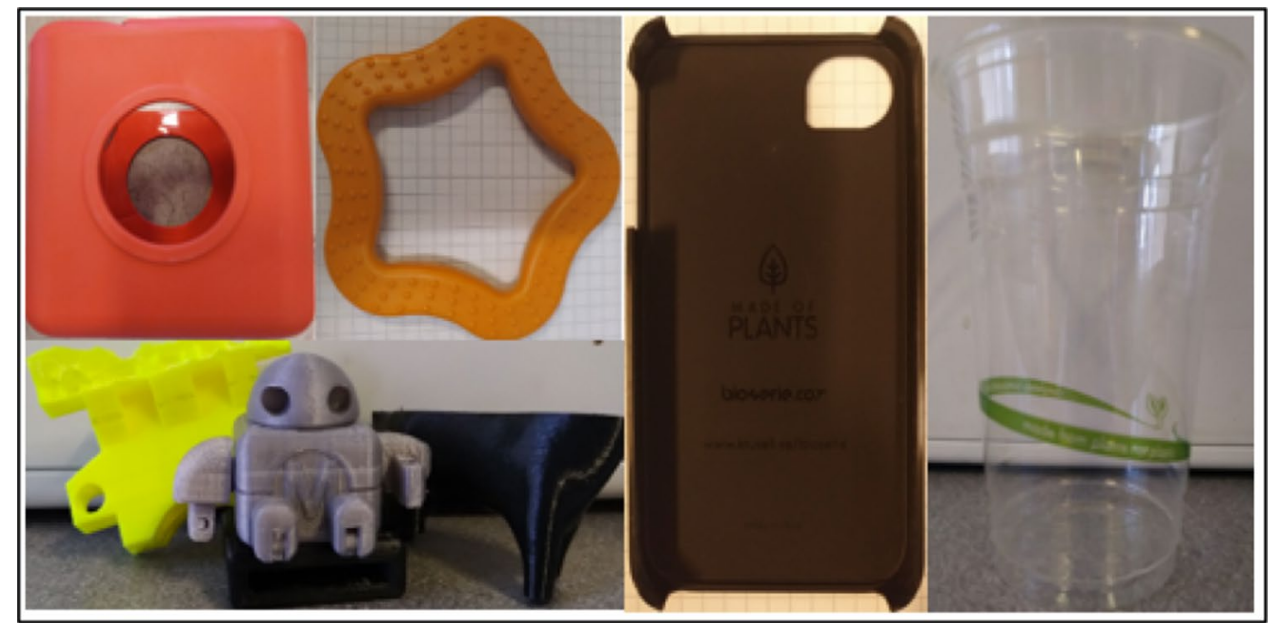

Table 1 PLA samples number average molecular weight $\left(M_{n}\right)$, dispersity $(\bigoplus)$ and source

\begin{tabular}{llll}
\hline PLA sample & $M_{n}\left(\mathrm{~g} \mathrm{~mol}^{-1}\right)$ & $D$ & Original source \\
\hline Phone case & 37,600 & 1.87 & Bioserie \\
Toy & 36,050 & 2.02 & Bioserie \\
Film & 69,800 & 1.65 & A. Warne \\
Cup & 45,150 & 2.08 & Vegware \\
3D Print & 65,100 & 2.12 & RS Components \\
\hline
\end{tabular}

Values include a 0.58 correction factor [24]

number average molecular weight $\left(M_{n}\right)$, dispersity $(\nexists)$ and source of the post-consumer PLA samples as well as their original source is presented in Table 1.

From the prior experimental work conducted and further statistical analysis it became indicative that the size of the PLA waste particle had very little influence upon the alkyl lactate selectivity and yield at the parameters tested [24]. For the current research, it was then decided that the PLA sample dimensions would not need to be uniform yet still small enough to conform to the reactor volume.

Ethanol absolute (HPLC grade, 99.8\% purity) was purchased from Sigma-Aldrich whereas THF solvent (HPLC grade, $99.9 \%$ purity, inhibitor free) from Fisher Scientific. Nitrogen (oxygen free) and helium (CP grade) were purchased from BOC.

Catalyst $\mathrm{Zn}\left(2^{\mathrm{Pr}}\right)_{2}$ was prepared under an inert atmosphere using Schlenk line techniques with dried solvents and stored in a glovebox prior to use. Details of the catalyst synthesis can be found elsewhere [43]. Catalyst concentration with respect to the PLA mass was kept constant at 8\% throughout all experiments. The PLA sample concentration with respect to total volume was constant at $0.05 \mathrm{~g} \mathrm{~mL}^{-1}$.

Refractive index gel permeation chromatography (GPC) was used to determine the $M_{n}$ and $\oslash$ of the PLA samples (Table 1). GPC was conducted at $1 \mathrm{~mL} \mathrm{~min}^{-1}$ at $35^{\circ} \mathrm{C}$ with a THF eluent using a PLgel $5 \mu \mathrm{m}$ MIXED-D $300 \times 7.5 \mathrm{~mm}$ column. 11 narrow molecular weight polystyrene standards were used as a reference system.

The experimental procedure was as follows: post-consumer PLA samples were first cut or broken down into sizable pieces. PLA sample $(12.50 \mathrm{~g})$, catalyst $(1.00 \mathrm{~g})$, THF $(200 \mathrm{~mL})$ and ethanol $(50 \mathrm{~mL})$ were charged into the reactor. The reactor vessel was sealed and the stirring speed was set to $870 \mathrm{rpm}$ based on previous studies showing an effect of stirring speed on reaction rate [42]. The reaction temperature was set to either $50{ }^{\circ} \mathrm{C}$ or $90^{\circ} \mathrm{C}$. The timing of the reaction commenced with the start of the heating process. The extra time needed to reach $90^{\circ} \mathrm{C}$ from $50{ }^{\circ} \mathrm{C}$ was around $7 \mathrm{~min}$. The effect of this heating time upon degradation at $90{ }^{\circ} \mathrm{C}$ was neglected.

Flushing the system proceeded for at least 20 min with nitrogen to remove any oxygen and moisture to create an inert atmosphere. Samples were collected at $1 \mathrm{~h}$ and $3 \mathrm{~h}$ and analysed by gas chromatography (GC) and Nuclear Magnetic Resonance spectroscopy ( ${ }^{1} \mathrm{H}$ NMR). GC was used to assess the concentration of EtLa. The samples were injected to the GC (Agilent Technologies, $6890 \mathrm{~N}$ ) by an autosampler (Agilent Technologies, 7683B), to a $30 \mathrm{~m} \times 0.32 \mathrm{~mm}$ ID, $0.25 \mu \mathrm{m}$ film thickness HP-5 Agilent capillary column. The following conditions were used: helium carrier gas, inlet temperature of $150{ }^{\circ} \mathrm{C}, 1 \mu \mathrm{L}$ injection volume, 1:100 split ratio and $250{ }^{\circ} \mathrm{C}$ detector temperature. Initial oven temperature of $90{ }^{\circ} \mathrm{C}$ (held for $4 \mathrm{~min}$ ), then $100{ }^{\circ} \mathrm{C} \mathrm{min}{ }^{-1}$ ramp to $120^{\circ} \mathrm{C}$ (held for $1 \mathrm{~min}$ ), followed by $100^{\circ} \mathrm{C} \mathrm{min}^{-1}$ ramp to $200{ }^{\circ} \mathrm{C}$ (held for $3 \mathrm{~min}$ ). Initial flowrate was $0.7 \mathrm{~mL} \mathrm{~min}^{-1}$ (held for $5 \mathrm{~min}$ ), then $100 \mathrm{~mL} \mathrm{~min}^{-1}$ ramp to $3 \mathrm{~mL} \mathrm{~min}^{-1}$. The GC was calibrated by preparing a multiple point external standard calibration curve covering the predicted EtLa concentration range with a linear response of the FID detector $\left(\mathrm{R}^{2}=0.999\right)$.

The ${ }^{1} \mathrm{H}$ NMR analysis was performed in $\mathrm{C}_{6} \mathrm{D}_{6}$ on a $400 \mathrm{MHz}$ Bruker Avance III spectrometer and referenced to 
residual solvent resonances. ${ }^{1} \mathrm{H}$ NMR determined the amount of internal (Int, 5.0-5.1 ppm), Chain-End (CE, 4.9-5.0 ppm and 4.1-4.2 ppm) and EtLa (4.0-4.1 ppm) methine groups, related to the amounts of PLA, intermediate and product as discussed elsewhere [24]. For clarity, the reaction scheme and the methine group assignation is presented in Fig. 4.

\section{Results and Discussion}

The concentrations of EtLa, as determined by GC, at $1 \mathrm{~h}$ and $3 \mathrm{~h}$ for all samples are presented in Fig. 5. It is clear that as time proceeds, more PLA is degraded and converted into valuable EtLa across each sample series. It can be observed that at $1 \mathrm{~h}$, the EtLa concentration at $90{ }^{\circ} \mathrm{C}$ exceeds that at $50{ }^{\circ} \mathrm{C}$ for each PLA sample. However, the same pattern cannot be associated with the $3 \mathrm{~h}$ time where both, the cup and 3D print material samples attain a higher product concentration at $50{ }^{\circ} \mathrm{C}$. This observation is in agreement with the work conducted by Román-Ramírez et al. [42] proposing that the $\mathrm{Zn}\left(2^{\mathrm{Pr}}\right)_{2}$ complex demonstrates greater activity at lower temperatures. The remaining samples indicate perhaps a more predictable catalytic behaviour, such as that observed for the $\operatorname{Zn}\left(1^{\mathrm{Et}}\right)_{2}$ complex [42], where at higher temperatures over a specific time, greater yields and catalyst activity become apparent. For example, the PLA film, markedly generated the highest EtLa concentration of all tests at $70.8 \mathrm{~g} \mathrm{dm}^{-3}\left(0.599 \mathrm{~mol} \mathrm{dm}^{-3}\right)$ over $3 \mathrm{~h}$ at
Fig. 4 Reaction scheme and typical ${ }^{1} \mathrm{H}$ NMR spectrum with methine group assignations for a PLA degradation sample (3D Print)

Fig. 5 Ethyl lactate concentrations as determined by GC. Error bars corresponds to 5\% estimated error
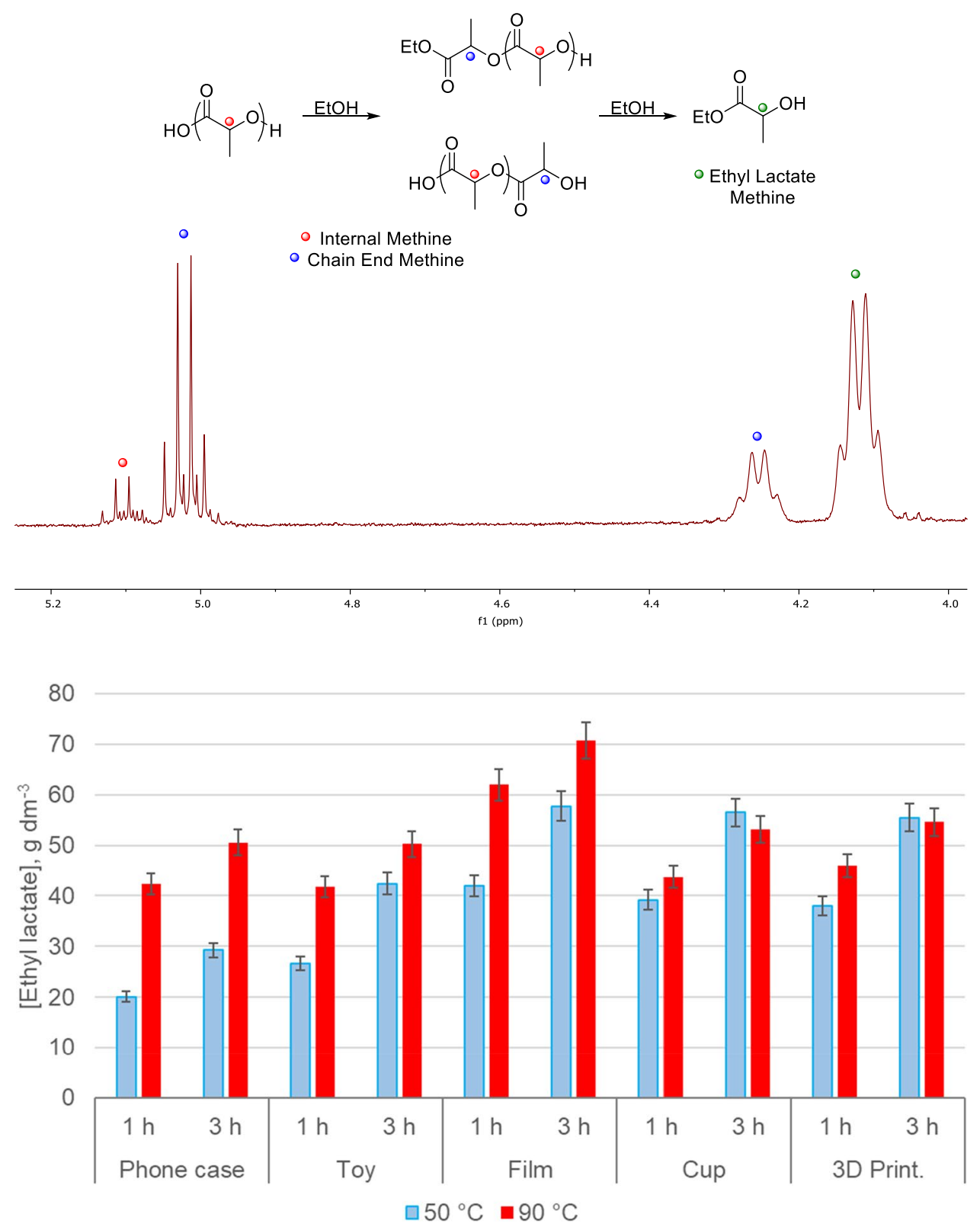
$90{ }^{\circ} \mathrm{C}$, which is closer to the maximum theoretical value of $82 \mathrm{~g} \mathrm{dm}^{-3}$ (assuming the whole sample mass corresponds to PLA only). Since the low PLA film thickness $(40 \mu \mathrm{m})$, it is possible that enhanced mass transfer more dramatically improves faster dissolution, resulting in improved degradation and finally in higher yields. However, considering the findings of Román-Ramírez et al. [24] reporting no mass transfer limitations after testing various rpm and particle sizes of neat PLA grades, it is plausible that the PLA film could also contain fewer additives compared with the rest of the samples. In contrast with every other test, the phone case and toy exhibited little dissolution at $50{ }^{\circ} \mathrm{C}$ and a low EtLa production even after $3 \mathrm{~h}$. Dissimilar to the PLA film, structurally the phone case and toy are designed to be durable, hard and strong in order to successfully fulfil their intended functions. Numerous additives present in PLA products, aimed to improve their specific performance, can also affect the reaction kinetics and the output composition. Common additives found include colorants, plasticisers, light stabilisers, thickeners and anti-bacterial agents [51]. Despite their relatively low $M_{n}$ (Table 1 ), the phone case and toy were structurally strong, likely related to the presence of additives [51, 52]. In fact, ${ }^{1} \mathrm{H}$ NMR analysis on the toy sample (spectrum not shown) revealed the signals of compounds other than the ones assigned for PLA, intermediates and product; however, a complete characterization was not possible. Moreover, the sample piece dimensions entering the reactor were relatively large (around $15 \mathrm{~mm}$ ) and could pose a mass transfer limitation. It is conceivable that the presence or lack of certain additives in bioplastics can not only improve their performance but inhibit dissolution $[6,52]$. For example, phthalates which are additives commonly used as plasticisers to enhance durability present a challenge when attempting to recycle [53]. Equally, crosslinking agents, for instance, have been reported to lower degradation rates [6]. However, when the reaction proceeded at $90{ }^{\circ} \mathrm{C}$, both samples, phone case and toy, were observed to fully dissolve and attain almost identical EtLa concentrations between 0.425 and $0.428 \mathrm{~mol} \mathrm{dm}^{-3}$ after $3 \mathrm{~h}$. Furthermore, these values are comparable to most PLA sample series at $90{ }^{\circ} \mathrm{C}$. Therefore, depending upon the PLA waste composition, the temperature employed and perhaps the particle size, it is evident that if poor sample dissolution occurs, the yield of EtLa is affected.

It was initially postulated that there may exist a strong link between $M_{n}, \nexists$, and the degradation time; however, the results did not show a direct correlation. For instance, the toy has a $Ð$ of 2.02, intermediate of the cup and film, yet generated less EtLa than both after $3 \mathrm{~h}$. Despite the difference in $M_{n}$ between the cup and 3D print material $\left(20,000 \mathrm{~g} \mathrm{~mol}^{-1}\right)$ similar final concentrations were obtained at both temperatures. The lack of correlation of these properties intrinsic to the biopolymers, further suggests that additives or the lack thereof in bioplastics, and mass transfer limitations, account for the EtLa variation across the PLA samples.

The values of the concentrations for the Int, $C E$ and EtLa methine groups for each sample are presented in Table 2, and the corresponding calculated conversion $(X)$, selectivity $(S)$ and yield $(Y)$ in Figs. 6, 7, and 8. Error bars correspond to $5 \%$ error based on previous studies [50]. High levels of degradation (conversions $>85 \%$ ) are achieved for all the post-consumer PLA samples demonstrating the versatility of the depolymerisation system. Conversions at $3 \mathrm{~h}$ were, as expected, higher than the $1 \mathrm{~h}$ mark. The degradation at $90{ }^{\circ} \mathrm{C}$ generally resulted in the higher conversions than at $50{ }^{\circ} \mathrm{C}$, except for the cup and
Fig. 6 PLA conversions. Conversion $=1-\frac{I n t}{100}$

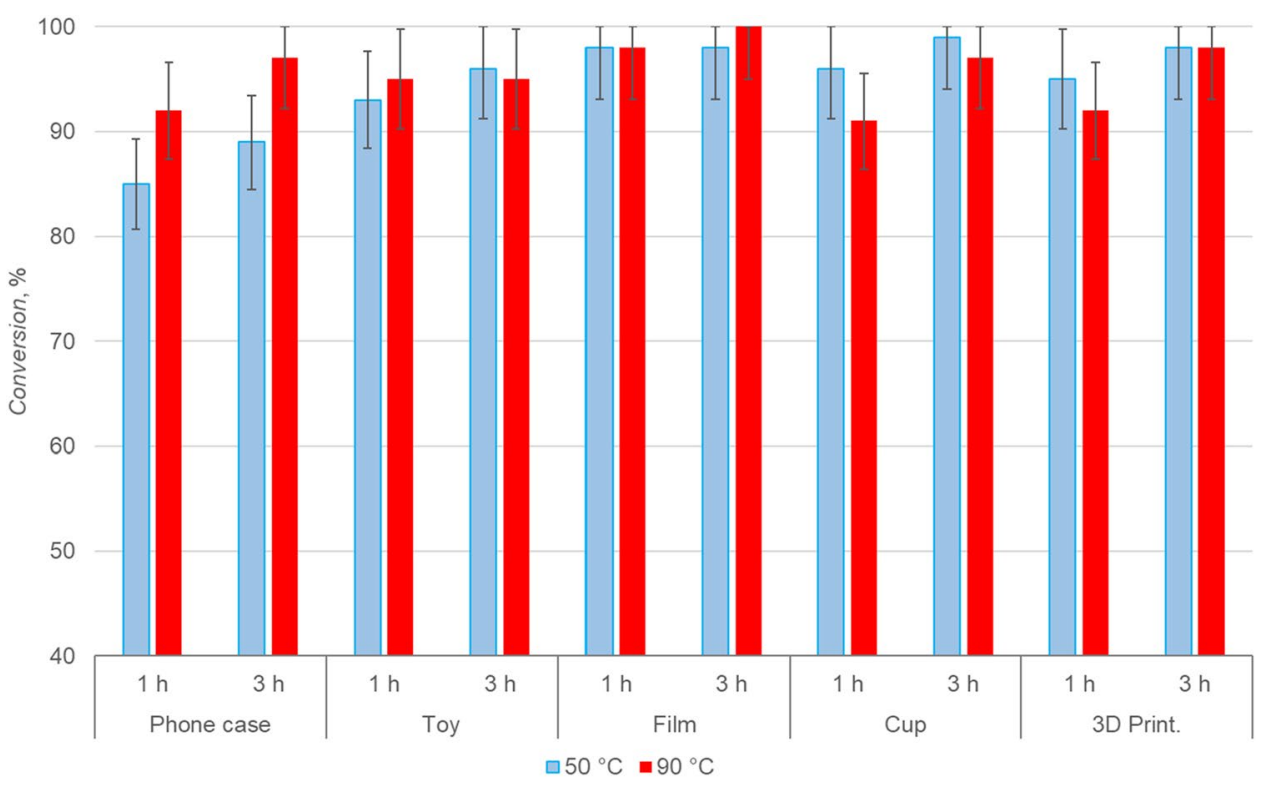


Fig. 7 Ethyl lactate selectivities. Selectivity $=\frac{E t L a}{100-\operatorname{In} t}$

Fig. 8 Ethyl lactate yields. Yield $=$ Conversion $\times$ Selectivity

Table 2 Concentration of Internal (Int), Chain-end $(C E)$ and ethyl lactate $(E t L a)$ methine groups determined by ${ }^{1} \mathrm{H}$ NMR analysis
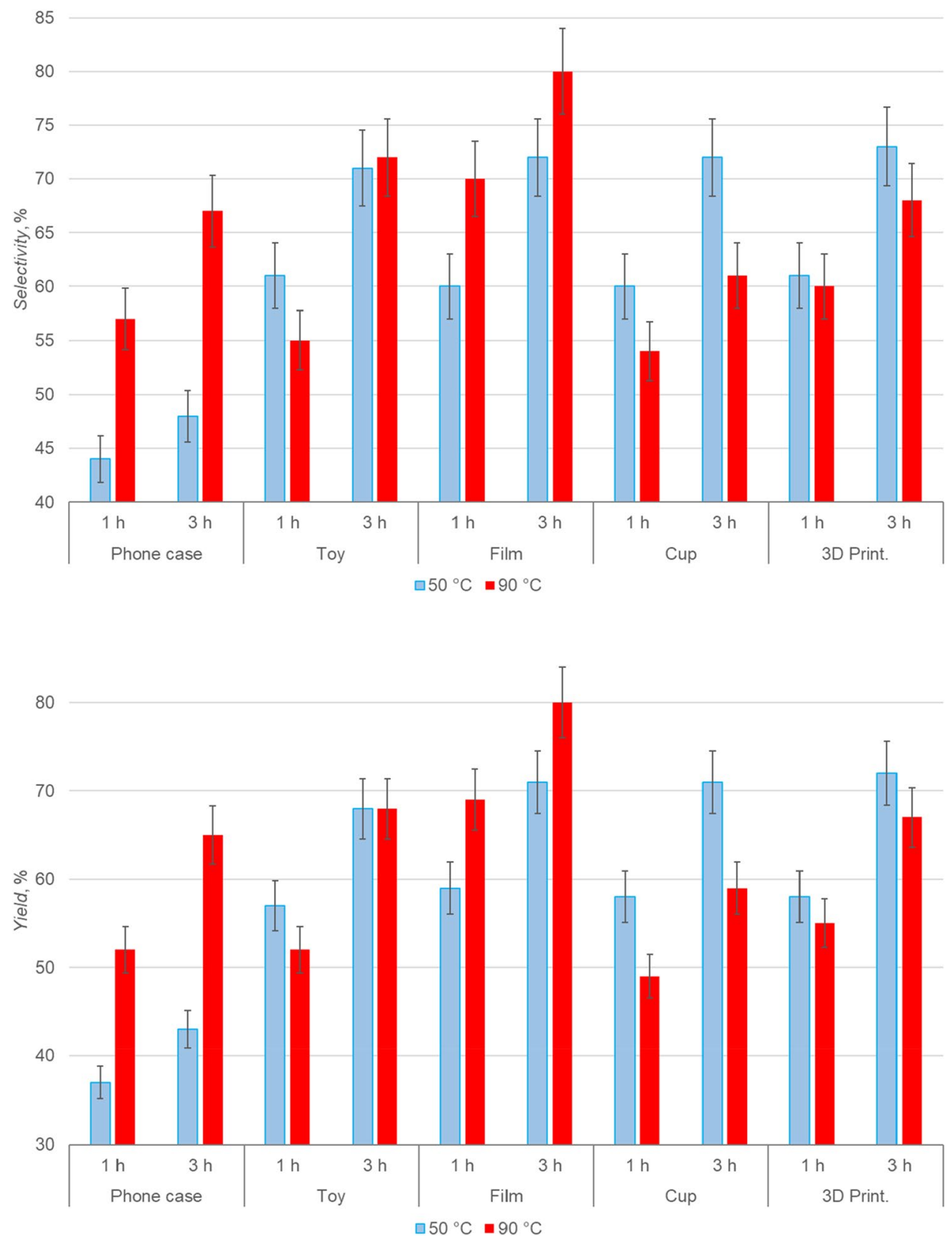

\begin{tabular}{|c|c|c|c|c|c|c|c|}
\hline \multirow[t]{2}{*}{ PLA sample } & \multirow[t]{2}{*}{ Time (h) } & \multicolumn{2}{|l|}{ Int,$\%$} & \multicolumn{2}{|l|}{$C E, \%$} & \multicolumn{2}{|c|}{ EtLa, \% } \\
\hline & & $50^{\circ} \mathrm{C}$ & $90^{\circ} \mathrm{C}$ & $50^{\circ} \mathrm{C}$ & $90^{\circ} \mathrm{C}$ & $50^{\circ} \mathrm{C}$ & $90^{\circ} \mathrm{C}$ \\
\hline \multirow[t]{2}{*}{ Phone case } & 1 & 15 & 8 & 48 & 40 & 37 & 52 \\
\hline & 3 & 11 & 3 & 46 & 32 & 43 & 65 \\
\hline \multirow[t]{2}{*}{ Toy } & 1 & 7 & 5 & 36 & 43 & 57 & 52 \\
\hline & 3 & 4 & 5 & 29 & 26 & 68 & 68 \\
\hline \multirow[t]{2}{*}{ Film } & 1 & 2 & 2 & 39 & 29 & 59 & 69 \\
\hline & 3 & 2 & 0 & 28 & 20 & 71 & 80 \\
\hline \multirow[t]{2}{*}{ Cup } & 1 & 4 & 9 & 39 & 42 & 58 & 49 \\
\hline & 3 & 1 & 3 & 28 & 38 & 71 & 59 \\
\hline \multirow[t]{2}{*}{ 3D Print } & 1 & 5 & 8 & 37 & 37 & 58 & 55 \\
\hline & 3 & 2 & 2 & 26 & 31 & 72 & 67 \\
\hline
\end{tabular}


the $3 \mathrm{D}$ print material. A conversion of $100 \%$ was possible at $3 \mathrm{~h}$ at $90{ }^{\circ} \mathrm{C}$ for the film, most likely related to its high solubility. The lowest conversion was achieved by the phone case. Similar trends of the conversion are observed for the selectivity and yield. A maximum $80 \%$ yield was obtained for the film whereas the lowest value was given by the phone case, due to its poor solubility, particularly at $50{ }^{\circ} \mathrm{C}$, and possible high additives content.

Comparing the work reported by Román-Ramírez et al. [24] after $1 \mathrm{~h}$ and under $90{ }^{\circ} \mathrm{C}$, the various PLA neat grades displayed typically greater yields over the current research waste samples. For instance, the highest EtLa yield reached 69\% whereas the MeLa yield peaked at $100 \%$ for the virgin polymer (NatureWorks Ingeo ${ }^{\mathrm{TM}}$ 4043D grade). Reasoning for such observations previously discussed include the presence of additives and possible mass transfer limitations. However, it is also conceivable that the protic agent, ethanol, employed in the present work, could be more sterically hindered than methanol on approach to the carbonyl centre. A study by Ali [54] investigated this factor through the esterification of an acid with alcohols and discovered that a greater carbon chain length decreases conversion. Similarly, Carné Sánchez and Collinson [55] found higher reactivity of ethanol compared with methanol when studying the alcoholysis of PLA. Hence, in the current work, alkyl lactate production with methanol may induce a higher yield than ethanol in this manner. Another potential explanation is the limit in catalytic activity at such temperatures. As discussed, previous research determined that at lower temperatures the $\operatorname{Zn}\left(2^{\mathrm{Pr}}\right)_{2}$ complex was found to be more active than $\mathrm{Zn}\left(\mathbf{1}^{\mathrm{Et}}\right)_{2}$ [42], which is in agreement with the experimental observations in this work. For example, between 40 and $60{ }^{\circ} \mathrm{C}$ under the $\operatorname{Zn}\left(1^{\mathrm{Et}}\right)_{2}$ catalyst, Román-Ramírez, et al. [24] achieved yields ranging from 0 to $48 \%$. Whereas, in the current research at $50{ }^{\circ} \mathrm{C}$ over $1 \mathrm{~h}$, most yields exceeded $50 \%$. These results indicate that the $\operatorname{Zn}\left(2^{\mathrm{Pr}}\right)_{2}$ complex may be used effectively for catalytic degradation at low temperatures, which implicates lower operating costs, higher profit margins and more incentive to utilise such a process.

Previous research conducted on the chemical recycling of PLA into alkyl lactates exhibit high yields under greater temperatures. Petrus et al. [41] using an Mg complex demonstrated the possibility to direct the transesterification of PLA. Despite exceptionally high EtLa yields approaching $86 \%$ over $1 \mathrm{~h}$, the use of high temperatures $\left(200^{\circ} \mathrm{C}\right)$ could reduce the likeliness of a profitable process. As already mentioned, under milder conditions of $100-150{ }^{\circ} \mathrm{C}$, relatively high yield routes in several hours are permissible such as those reported by Brake [40] and Song et al. [46]. These observations can be explained by a trade-off between rising temperatures and faster kinetics, along with varying catalytic activity.

\section{Conclusions}

The present work investigated the catalytic depolymerisation of five post-consumer PLA samples into the green solvent ethyl lactate. Conforming to a circular economy, the transesterification of waste PLA with protic ethanol is directed by a propylendiamine $\mathrm{Zn}(\mathrm{II})$ complex. This complex demonstrated greater activity at lower temperatures deriving in higher ethyl lactate yields and selectivities at $50{ }^{\circ} \mathrm{C}$ over $3 \mathrm{~h}$ than at $90{ }^{\circ} \mathrm{C}$ for the cup and 3D print samples. The durable phone case and toys suffered from poor dissolution at $50{ }^{\circ} \mathrm{C}$ resulting in lower conversions, selectivities and yields, whereas the opposite was the case for the fine film sample. Polymer molecular weight and dispersity offered little explanation on conversion, selectivity and yield, it was therefore surmised that the rate of PLA waste sample degradation was dependent upon additives and the extent of sample dissolution. Other suggestions on the effect on yield are the steric hindrance of ethanol compared with methanol. Despite the presence of unknown additives, the catalytic system can produce valuable ethyl lactate from a variety of post-consumer PLA samples.

Acknowledgements The authors would like to acknowledge the financial support of ESPRC (EP/P016405/1). The Food Microstructure research group at the University of Birmingham are acknowledged for their donation of 3D printing samples. A. Warne Co. Ltd is acknowledged for their donation of PLA film.

Data Availability Data associated with this publication is available free of charge at edata.bham.ac.uk.

Open Access This article is licensed under a Creative Commons Attribution 4.0 International License, which permits use, sharing, adaptation, distribution and reproduction in any medium or format, as long as you give appropriate credit to the original author(s) and the source, provide a link to the Creative Commons licence, and indicate if changes were made. The images or other third party material in this article are included in the article's Creative Commons licence, unless indicated otherwise in a credit line to the material. If material is not included in the article's Creative Commons licence and your intended use is not permitted by statutory regulation or exceeds the permitted use, you will need to obtain permission directly from the copyright holder. To view a copy of this licence, visit http://creativecommons.org/licenses/by/4.0/.

\section{References}

1. British Plastics Federation (2020) Plastics applications. https:// www.bpf.co.uk/plastipedia/applications/default.aspx. Accessed 15 Jan 2020 
2. Geyer R, Jambeck JR, Law KL (2017) Sci Adv 3:e1700782. https ://doi.org/10.1126/sciadv.1700782

3. Carraher CE Jr (2003) Polymer chemistry, 6th edn. Marcel Dekker Inc, New York

4. Li WC, Tse HF, Fok L (2016) Sci Total Environ 566-567:333. https://doi.org/10.1016/j.scitotenv.2016.05.084

5. Yu D (2016) Polychlorinated biphenyls (PCBs) toxicity. Department of Health and Human Services. Agency for Toxic Substances and Disease Registry (ATSDR), U.S. https://www.atsdr .cdc.gov/csem/csem.asp?csem $=30 \&$ po $=10$

6. Niaounakis M (2013) Biopolymers: reuse, recycling, and disposal. Elsevier, Amsterdam

7. Sin LT, Rahmat AR, Rahman WAWA (2013) Applications of poly(lactic Acid). In: Ebnesajjad S (ed) Polylactic acid. William Andrew Publishing, Oxford, p 301

8. Van den Eynde M, Van Puyvelde P (2018) 3D printing of poly(lactic acid). In: Di Lorenzo ML, Androsch R (eds) Industrial applications of poly(lactic acid). Springer, Cham, p 139

9. Smithers (2019) The future of bioplastics for packaging to 2024. https://www.smithers.com/services/market-reports/packaging/ bioplastics-for-packaging-to-2024. Accessed July 2019

10. Torres A, Li SM, Roussos S, Vert M (1996) J Appl Polym Sci 62:2295. https://doi.org/10.1002/(SICI)1097-4628(19961 226)62:13<2295:AID-APP14>3.0.CO;2-2

11. Wilfred O, Tai H, Marriott R et al (2018) Int J Nano Res 1:1

12. Ndazi BS, Karlsson S (2011) eXPRESS Polym Lett 5:119. https ://doi.org/10.3144/expresspolymlett.2011.13

13. Betts K (2008) Environ Sci Technol 42:8996. https://doi. org/10.1021/es802970v

14. de Souza Machado AA, Kloas W, Zarfl C et al (2018) Glob Change Biol 24:1405. https://doi.org/10.1111/gcb.14020

15. Hopewell J, Dvorak R, Kosior E (2009) Philos Trans R Soc A 364:2115. https://doi.org/10.1098/rstb.2008.0311

16. Ragaert K, Delva L, Van Geem K (2017) Waste Manag 69:24. https://doi.org/10.1016/j.wasman.2017.07.044

17. Piemonte V, Sabatini S, Gironi F (2013) J Polym Environ 21:640. https://doi.org/10.1007/s10924-013-0608-9

18. Hong M, Chen EYX (2017) Green Chem 19:3692. https://doi. org/10.1039/C7GC01496A

19. Piemonte V, Gironi F (2013) J Polym Environ 21:313. https://doi. org/10.1007/s10924-012-0547-x

20. Herrera-Kao WA, Loría-Bastarrachea MI, Pérez-Padilla Y et al (2018) Polym Bull 75:4191. https://doi.org/10.1007/s0028 9-017-2260-3

21. Vogel C, Siesler HW (2008) Macromol Symp 265:183. https:// doi.org/10.1002/masy.200850520

22. Oda Y, Yonetsu A, Urakami T, Tonomura K (2000) J Polym Environ 8:29. https://doi.org/10.1023/A:1010120128048

23. Lee SH, Kim IY, Song WS (2014) Macromol Res 22:657. https:// doi.org/10.1007/s13233-014-2107-9

24. Román-Ramírez LA, McKeown P, Jones MD, Wood J (2019) ACS Catal 1:409. https://doi.org/10.1021/acscatal.8b04863

25. Chapman J, Ismail A, Dinu C (2018) Catalysts 8:1. https://doi. org/10.3390/catal 8060238

26. Noda M, Okuyama H (1999) Chem Pharm Bull 47:467. https:// doi.org/10.1248/cpb.47.467

27. Codari F, Lazzari S, Soos M et al (2012) Polym Degrad Stab 97:2460. https://doi.org/10.1016/j.polymdegradstab.2012.06.026

28. Pereira CSM, Silva VMTM, Rodrigues AE (2011) Green Chem 13:2658. https://doi.org/10.1039/C1GC15523G

29. Doble M, Kruthiventi AK (2007) Green chemistry and engineering. Elsevier, Amsterdam
30. Volodymyr B, Varvarin A, Svetlana L, Ya G (2019) Ukr Chem J 85:31. https://doi.org/10.33609/0041-6045.85.7.2019.31-37

31. De Clercq R, Dusselier M, Poleunis C et al (2018) ACS Catal 8:8130. https://doi.org/10.1021/acscatal.8b02216

32. De Clercq R, Dusselier M, Makshina E, Sels BF (2018) Angew Chem Int Ed 57:3074. https://doi.org/10.1002/anie.201711446

33. Upare PP, Hwang YK, Chang J-S, Hwang DW (2012) Ind Eng Chem Res 51:4837. https://doi.org/10.1021/ie202714n

34. Egiazaryan TA, Makarov VM, Moskalev MV et al (2019) Mendeleev Commun 29:648. https://doi.org/10.1016/j.menco m.2019.11.014

35. Asthana NS, Kolah AK, Vu DT et al (2006) Ind Eng Chem Res 45:5251. https://doi.org/10.1021/ie0513604

36. Delgado P, Sanz MT, Beltrán S (2008) Sep Purif Technol 64:78. https://doi.org/10.1016/j.seppur.2008.08.002

37. Martino-Gauchi G, Teissier R (2007) Continuous method for preparing ethyl lactate, U.S. Patent 7297809

38. Hirao K, Nakatsuchi Y, Ohara H (2010) Polym Degrad Stab 95:925. https://doi.org/10.1016/j.polymdegradstab.2010.03.027

39. Leibfarth FA, Moreno N, Hawker AP, Shand JD (2012) J Polym Sci Part A 50:4814. https://doi.org/10.1002/pola.26303

40. Brake LD (1993) Preparation of alkyl esters by depolymerization U.S. Patent 5264617

41. Petrus R, Bykowski D, Sobota P (2016) ACS Catal 6:5222. https ://doi.org/10.1021/acscatal.6b01009

42. Román-Ramírez LA, McKeown P, Jones MD, Wood J (2020) ACS Omega 5:5556. https://doi.org/10.1021/acsomega.0c00291

43. McKeown P, Román-Ramírez LA, Bates S et al (2019) Chemsuschem 12:5233. https://doi.org/10.1002/cssc.201902755

44. Wu M, He W (1995) Process of manufacture of ethyl lactate, C.N. Patent 1102180

45. Gupta P, Paul S (2014) Catal Today 236:153. https://doi. org/10.1016/j.cattod.2014.04.010

46. Song X, Zhang X, Wang H et al (2013) Polym Degrad Stab 98:2760. https://doi.org/10.1016/j.polymdegradstab.2013.10.012

47. Alberti C, Damps N, Meißner RRR, Enthaler S (2019) ChemistrySelect 4:6845. https://doi.org/10.1002/slct.201901316

48. Alberti C, Damps N, Meißner RRR et al (2019) Adv Sustain Syst. https://doi.org/10.1002/adsu.201900081

49. Hofmann M, Alberti C, Scheliga F et al (2020) Polym Chem 11:2625. https://doi.org/10.1039/D0PY00292E

50. Román-Ramírez LA, McKeown P, Shah C et al (2020) Ind Eng Chem Res. https://doi.org/10.1021/acs.iecr.0c01122

51. British Plastics Federation Plastics Additives. https://www.bpf co.uk/plastipedia/additives/default.aspx. Accessed 25 Oct 2019

52. Hahladakis JN, Velis CA, Weber R et al (2018) J Hazard Mater 344:179. https://doi.org/10.1016/j.jhazmat.2017.10.014

53. Pivnenko K, Eriksen MK, Martín-Fernández JA et al (2016) Waste Manag 54:44. https://doi.org/10.1016/j.wasman.2016.05.014

54. Ali SH (2009) Int J Chem Kinet 41:432. https://doi.org/10.1002/ kin.20416

55. Carné Sánchez A, Collinson SR (2011) Eur Polym J 47:1970. https://doi.org/10.1016/j.eurpolymj.2011.07.013

Publisher's Note Springer Nature remains neutral with regard to jurisdictional claims in published maps and institutional affiliations. 